ISSN 0258-7122 (Print), 2408-8293 (Online)

Bangladesh J. Agril. Res. 44(2): 367-376, June 2019

\title{
EFFECT OF GA 3 AND NAA ON GROWTH AND YIELD OF CABBAGE
}

\author{
M. MONIRUZZAMAN ${ }^{1}$, R. KHATOON ${ }^{2}$, M. MONIRUZZAMAN $^{3}$ \\ AND M. M. RAHMAN ${ }^{4}$
}

\begin{abstract}
A field experiment was conducted at the Plant Physiology Field of Horticulture Research Center (HRC), Bangladesh Agricultural Research Institute, Gazipur during the rabi seasons of 2015-16 and 2016-17 to study the response of cabbage (var. Krishibid Hybrid-1 and Atlas-70) to foliar application of $\mathrm{GA}_{3}$ and NAA with different concentrations. The experiment was laid out in a Randomized Complete block Design with three replications. The experiment consisted of eight treatments viz., three levels of $\mathrm{GA}_{3}$ (at 50, 75 and $100 \mathrm{ppm}$ ) and four levels of NAA (at 40, 60, 80 and $100 \mathrm{ppm}$ ) along with distilled water as control. The varieties Krishibid Hybrid-1 and Atlas-70 were used in 2015-16 and 2016-17, respectively. Foliar spray of $\mathrm{GA}_{3}$ and NAA was given at 25 and 45 days after transplanting of seedling. The results of the investigation indicated significant differences among the treatments on most of the parameters studied. In Krishibid Hybrid-1, application of 50 ppm $\mathrm{GA}_{3}$ and 60 ppm NAA increased plant height, plant spread, number of leaves, chlorophyll content, head height, head diameter, single head weight without unfolded leaves as well as head yield (81.18 t/ha for $50 \mathrm{ppm} \mathrm{GA}_{3}$ and $78.57 \mathrm{t} / \mathrm{ha}$ for $60 \mathrm{ppm}$ NAA) than the control $(67.29 \mathrm{t} / \mathrm{ha})$ and other treatments. But, in Atlas-70, application of $75 \mathrm{ppm} \mathrm{GA}$ gave the maximum values of most of the growth parameters, yield components and yield (102.40 t/ha), which was followed by $50 \mathrm{ppm} \mathrm{GA}$ (94.96 t/ha). In Krishibid Hybrid-1, application of 60 ppm NAA gave the highest benefit-cost ratio (BCR) of 3.63 followed by 75 ppm GA GA $_{3}$ (3.59) while in Atlas-70, $75 \mathrm{ppm}$ $\mathrm{GA}_{3}$ recorded the highest BCR of 4.79 followed by 50 ppm GA 3 (4.54) and 60 ppm NAA (4.37). Therefore, application of GA 3 @50-75 ppm or NAA @ 60 ppm concentration can be recommended for increasing the yield of cabbage with higher return.
\end{abstract}

Keywords: Gibberellic Acid, Naphthalene Acetic Acid, Cabbage, Head yield, BCR.

\section{Introduction}

Cabbage (Brassica oleracea var. capitata L.) locally known as 'badhacopy' is an important leafy vegetables grown in winter season throughout Bangladesh. It is a member of the family Brassicaceae (or Cruciferae). It is a herbaceous, biennial,

${ }^{1}$ Principal Scientific Officer, Horticulture Research Center, Plant Physiology Section, Bangladesh Agricultural Research Institute (BARI), Gazipur, ${ }^{2 \& 3}$ Scientific Officer, Horticulture Research Center, Plant Physiology Section, BARI, Gazipur, ${ }^{4}$ Principal Scientific Officer (C.C) Regional Horticulture Research Station, Narsingdi, Horticulture Research Center, Plant Physiology Section, BARI, Gazipur, Bangladesh. 
dicotyledonous flowering plant distinguished by a short stem upon which is crowded mass of leaves, usually green but in some varieties red or purplish, which while immature form a characteristic compact, globular cluster known as cabbage head. The head is used as salad, boiled vegetable, cooked in curries, used in pickling as well as dehydrated vegetable. Cabbage head is an excellent source of many nutrients especially vitamin $\mathrm{C}$, vit. $\mathrm{B}_{6}$, vit. $\mathrm{K}$, folate, biotin, calcium, magnesium, potassium and manganese. It also contains significant amounts of glutamine, an amino acid that has anti-ulcer properties. Cabbage is a source of indole-3-carbinol, a chemical which boosts DNA repair in cells and appears to block the growth of cancer cells. The taste in cabbage is due to the "Sinigrin glucoside" (Singh et al., 2004).

There is a necessity of boosting up vegetable production to increase the per capita per day intake of vegetables in Bangladesh. Application of plant growth regulator is one of the best means for the increased vegetable production. Nowa- days, plant growth regulators have been tried to improve growth and ultimately yield. Growth regulators are organic compounds other than nutrients; small amounts of which are capable of modifying growth. Among the growth regulators, auxin causes enlargement of plant cell and gibberellins stimulates cell division, cell enlargement or both (Nickell, 1982). Gibberellic acid $\left(\mathrm{GA}_{3}\right)$ and Napthalene acetic acid (NAA) exhibited beneficial effect in several crops (Thapa et al., 2013; Mello et al, 2013; and Roy and Nasiruddin, 2011). Due to diversified use of productive land, it is necessary to increase food production and growth regulators may be a contributor in achieving the desired goal. Cabbage was found to show a quick growth, increase number of leaves/plant and higher yield when treated with plant growth regulator especially $\mathrm{GA}_{3}$ and NAA (Dhengle et al., 2008; Yadav et al., 2000; Kumar et al., 1996). A very little research work has been done on this aspect in Bangladesh. Therefore, the present investigation was undertaken to find out the appropriate concentration of $\mathrm{GA}_{3}$ and NAA for better growth and yield of cabbage.

\section{Materials and Methods}

The experiment was conducted at the field of plant physiology section of HRC during the rabi seasons of 2015-16 and 2016-17. The experiment was laid out in a Randomized Complete Block Design with 3 replications. Eight growth regulator treatments viz., $\mathrm{T}_{0}=$ Distilled water $\left(\right.$ control), $\mathrm{T}_{1}=\mathrm{GA}_{3} @ 50 \mathrm{ppm}, \mathrm{T}_{2}$

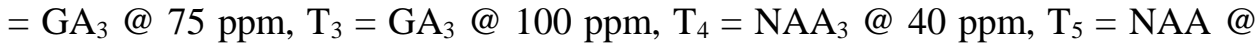
60 ppm, $\mathrm{T}_{6}=\mathrm{NAA} @ 80 \mathrm{ppm}$ and $\mathrm{T}_{7}=\mathrm{NAA} @ 100 \mathrm{ppm}$ were included in this study. The test varieties were Krishibid Hybrid-1 $\left(\mathrm{V}_{1}\right)$ and Atlas-70 $\left(\mathrm{V}_{2}\right)$; the former was used in 2015-16 but the latter was used in 2016-17. Twenty eight day-old seedlings were transplanted on 20 December, 2015 at $60 \mathrm{~cm} \mathrm{x} 40 \mathrm{~cm}$ spacing. But the twenty seven days old seedlings were transplanted on 22 December, 2016 at $60 \mathrm{~cm}$ x $50 \mathrm{~cm}$ spacing. In 2015-16 and 2016-17, the unit plot

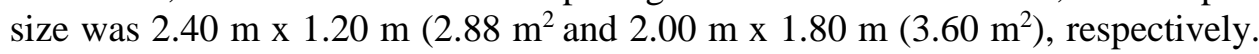


The seedlings were watered immediately after transplanting. Gap filling was done as and when required. Gibberellic acid $\left(\mathrm{GA}_{3}\right)$ and Naphthalene acetic acid (NAA) belong to the company Merck $\mathrm{KGaH}$, Germany. The growth regulators were sprayed at 25 and 45 days after transplanting. Control plants were sprayed with distilled water. The land was fertilized with 5.00 t/ha cowdung + $140-40$ 125- 30- 1.4- $5.00-2.00 \mathrm{~kg} / \mathrm{ha}$ of N-P-K-S-B-Zn-Mg (Anon., 2006). The sources of $\mathrm{N}, \mathrm{P}, \mathrm{K}, \mathrm{S}, \mathrm{B}, \mathrm{Zn}$ and $\mathrm{Mg}$ were urea, TSP, MoP, gypsum, boric acid (medicated), zinc sulphate and magnesium sulphate. The total amount of cowdung, $\mathrm{P}, \mathrm{S}, \mathrm{B}, \mathrm{Zn}, \mathrm{Mg}$ and one-third of each $\mathrm{N}$ and $\mathrm{K}$ were applied during land preparation. The rest of $\mathrm{N}$ and $\mathrm{K}$ were applied in two equal installments at 20 and 35 days after transplanting (DAT). Weeding was done as when necessary. A total of four irrigations were given to the crop. Head harvest of the variety Krishibid Hybrid-1 was done on 26 February 2016 to 03 March, 2016. But head harvest of the variety Atlas-70 was done on 28 February 2017 to 08 March, 2017. The data on plant height, plant spread, number of unfolded leaves, folded leaves and total leaves/plant, head height, head diameter, head diameter, head compactness, single head weight with unfolded leave, single head weight without unfolded leaves and head yield/plot were recorded at harvest. Chlorophyll content index (CCI) (taken by Chlorophyll Content Meter (Model:CCM-200, Opti-sciences, USA) was recorded at 55 days after transplanting (DAP). Head yield/plot was converted per hectare yield. Head compactness was measured in Newton (N) using Fruit texture Analyzer (GUSS, Model No. GS 25, SA). The MSTAT-C computer package was used to analyze the data. Mean separation was done by Tukey's W Test at $5 \%$ level of probability.

\section{Results and Discussion}

\section{Effect of $\mathrm{GA}_{3}$ and $\mathrm{NAA}$ on the growth parameters of cabbage}

The maximum plant height was recorded in the variety Krishibid Hybrid-1 from $\mathrm{GA}_{3}$ at $50 \mathrm{ppm}(26.40 \mathrm{~cm})$ which was statistically similar to NAA at $60 \mathrm{ppm}$ $(24.96 \mathrm{~cm}), \mathrm{GA}_{3}$ at $75 \mathrm{ppm}(24.82 \mathrm{~cm})$, and NAA at $80 \mathrm{ppm}(24.03 \mathrm{~cm})$, but in Atlas-70 the maximum plant height was recorded from $\mathrm{GA}_{3}$ at $75 \mathrm{ppm}(23.30$ $\mathrm{cm})$ which was statistically similar to NAA at $60 \mathrm{ppm}(22.78 \mathrm{~cm}), \mathrm{GA}_{3}$ at $50 \mathrm{ppm}$ $(22.50 \mathrm{~cm}), \mathrm{GA}_{3}$ at $100 \mathrm{ppm}(22.23 \mathrm{~cm})$ and NAA at $80 \mathrm{ppm}(21.93 \mathrm{~cm})($ Table 1). The control treatment gave the lowest plant height $(18.48 \mathrm{~cm}$ in Krishibid Hybrid-1 and $17.25 \mathrm{~cm}$ in Atlas-70). Application of $60 \mathrm{ppm}$ NAA gave the maximum plant spread $(65.12 \mathrm{~cm})$ which was statistically similar to $\mathrm{GA}_{3}$ at 50 $(64.90 \mathrm{~cm})$ and $75 \mathrm{ppm}(61.41 \mathrm{~cm})$, NAA at $40 \mathrm{ppm}(63.19 \mathrm{~cm})$ and NAA at 80 ppm $(62.51 \mathrm{~cm})$ in Krishibid Hybrid-1, but, in Atlas-70, application of $\mathrm{GA}_{3}$ at $75 \mathrm{ppm}$ produced the maximum plant spread $(57.80 \mathrm{~cm})$ which was identical to NAA at $60 \mathrm{ppm}(56.92 \mathrm{~cm})$. In both the varieties, the minimum plant spread was recorded in control treatment. These are in agreement with Moyazzama (2008), Chaurasiy et al. (2014), Mazed et al. (2015), Paul (2011) and Afrin (2013) who found maximum plant height and plant spread from the spray of $\mathrm{GA}_{3} @ 85,60$, 
90, 90 and 70 ppm. Roy and Nasiruddin (2011) obtained the highest plant height from $\mathrm{GA}_{3}$ at $75 \mathrm{ppm}$ being identical with $\mathrm{GA}_{3}$ at $50 \mathrm{ppm}$. But Islam et al. (2017) reported the highest plant height from the application of $\mathrm{GA}_{3}$ at $120 \mathrm{ppm}$ to the late planting (on 10 December, 2016) cabbage. Chaurasiy et al. (2014) recorded maximum plant height from 80 ppm NAA among 40, 80 and 120 ppm NAA.

Table 1. Effect of $\mathrm{GA}_{3}$ and NAA on the growth of cabbage

\begin{tabular}{c|ccc|c|c|c|c|c}
\hline \multirow{2}{*}{ Treat. } & \multicolumn{2}{|c|}{ Plant height (cm) } & \multicolumn{2}{c|}{ Plant spread (cm) } & \multicolumn{2}{c|}{$\begin{array}{c}\text { Days to head } \\
\text { initiation }\end{array}$} & \multicolumn{2}{c}{$\begin{array}{c}\text { *Days to head } \\
\text { maturity }\end{array}$} \\
\cline { 2 - 10 } & $\mathrm{V}_{1}$ & $\mathrm{~V}_{2}$ & $\mathrm{~V}_{1}$ & $\mathrm{~V}_{2}$ & $\mathrm{~V}_{1}$ & $\mathrm{~V}_{2}$ & $\mathrm{~V}_{1}$ & $\mathrm{~V}_{2}$ \\
\hline $\mathrm{T}_{0}$ & $18.48 \mathrm{~d}$ & $17.25 \mathrm{c}$ & $54.95 \mathrm{~d}$ & $46.81 \mathrm{~d}$ & $46.27 \mathrm{a}$ & 40.25 & $76.76 \mathrm{a}$ & $79.46 \mathrm{a}$ \\
$\mathrm{T}_{1}$ & $26.40 \mathrm{a}$ & $22.50 \mathrm{ab}$ & $64.90 \mathrm{ab}$ & $54.46 \mathrm{bc}$ & $38.59 \mathrm{~b}$ & 35.20 & $69.72 \mathrm{~cd}$ & $72.22 \mathrm{c}$ \\
$\mathrm{T}_{2}$ & $24.82 \mathrm{abc}$ & $23.30 \mathrm{a}$ & $61.41 \mathrm{abc}$ & $57.80 \mathrm{a}$ & $39.09 \mathrm{~b}$ & 35.42 & $73.95 \mathrm{abc}$ & $70.42 \mathrm{c}$ \\
$\mathrm{T}_{3}$ & $22.83 \mathrm{bc}$ & $22.23 \mathrm{abc}$ & $56.50 \mathrm{~cd}$ & $54.40 \mathrm{bc}$ & $40.61 \mathrm{ab}$ & 35.65 & $75.12 \mathrm{ab}$ & $72.62 \mathrm{c}$ \\
$\mathrm{T}_{4}$ & $23.10 \mathrm{bc}$ & $20.60 \mathrm{c}$ & $63.19 \mathrm{ab}$ & $53.34 \mathrm{c}$ & $40.78 \mathrm{ab}$ & 36.70 & $69.11 \mathrm{~d}$ & $74.64 \mathrm{bc}$ \\
$\mathrm{T}_{5}$ & $24.96 \mathrm{ab}$ & $22.78 \mathrm{a}$ & $65.12 \mathrm{a}$ & $56.92 \mathrm{ab}$ & $40.72 \mathrm{ab}$ & 35.35 & $69.75 \mathrm{~cd}$ & $70.45 \mathrm{c}$ \\
$\mathrm{T}_{6}$ & $24.03 \mathrm{abc}$ & $21.93 \mathrm{abc}$ & $62.51 \mathrm{ab}$ & $53.30 \mathrm{c}$ & $41.82 \mathrm{ab}$ & 36.82 & $70.40 \mathrm{bcd}$ & $73.82 \mathrm{bc}$ \\
$\mathrm{T}_{7}$ & $21.78 \mathrm{c}$ & $20.98 \mathrm{bc}$ & $59.38 \mathrm{bcd}$ & $53.85 \mathrm{bc}$ & $42.62 \mathrm{ab}$ & 36.90 & $75.00 \mathrm{ab}$ & $77.25 \mathrm{ab}$ \\
\hline $\mathrm{CV}(\%)$ & 4.55 & 4.82 & 3.19 & 3.11 & 4.94 & 5.18 & 2.28 & 3.99 \\
\hline
\end{tabular}

Table 1.cont'd

\begin{tabular}{c|cc|ccc|c}
\hline \multirow{2}{*}{ Treatment } & \multicolumn{2}{c|}{$\begin{array}{c}\text { Unfolded leaves/plant } \\
\text { (no.) }\end{array}$} & \multicolumn{2}{c|}{ Folded leaves/plant (no.) } & \multicolumn{2}{c}{ Total leaves/plant (no.) } \\
\cline { 2 - 7 } & $\mathrm{V}_{1}$ & $\mathrm{~V}_{2}$ & $\mathrm{~V}_{1}$ & $\mathrm{~V}_{2}$ & $\mathrm{~V}_{1}$ & $\mathrm{~V}_{2}$ \\
\hline $\mathrm{T}_{0}$ & $13.23 \mathrm{~d}$ & $11.17 \mathrm{~d}$ & $34.09 \mathrm{e}$ & $37.33 \mathrm{~d}$ & $47.09 \mathrm{c}$ & $48.60 \mathrm{f}$ \\
$\mathrm{T}_{1}$ & $16.46 \mathrm{a}$ & $13.40 \mathrm{ab}$ & $40.89 \mathrm{a}$ & $45.73 \mathrm{bc}$ & $57.35 \mathrm{a}$ & $59.13 \mathrm{bc}$ \\
$\mathrm{T}_{2}$ & $15.60 \mathrm{bc}$ & $13.60 \mathrm{a}$ & $38.79 \mathrm{bc}$ & $48.73 \mathrm{a}$ & $54.39 \mathrm{ab}$ & $62.33 \mathrm{a}$ \\
$\mathrm{T}_{3}$ & $15.54 \mathrm{bc}$ & $12.60 \mathrm{bc}$ & $34.92 \mathrm{e}$ & $45.60 \mathrm{bc}$ & $50.46 \mathrm{bc}$ & $58.20 \mathrm{bcd}$ \\
$\mathrm{T}_{4}$ & $15.41 \mathrm{bc}$ & $11.93 \mathrm{~cd}$ & $36.98 \mathrm{~d}$ & $43.53 \mathrm{c}$ & $52.39 \mathrm{ab}$ & $55.47 \mathrm{e}$ \\
$\mathrm{T}_{5}$ & $15.86 \mathrm{~b}$ & $13.47 \mathrm{ab}$ & $40.44 \mathrm{ab}$ & $46.67 \mathrm{ab}$ & $56.30 \mathrm{a}$ & $60.13 \mathrm{ab}$ \\
$\mathrm{T}_{6}$ & $15.26 \mathrm{c}$ & $12.40 \mathrm{c}$ & $38.25 \mathrm{~cd}$ & $43.83 \mathrm{c}$ & $53.51 \mathrm{ab}$ & $56.23 \mathrm{de}$ \\
$\mathrm{T}_{7}$ & $15.18 \mathrm{c}$ & $12.20 \mathrm{~cd}$ & $35.18 \mathrm{e}$ & $44.67 \mathrm{bc}$ & $50.36 \mathrm{ab}$ & $56.87 \mathrm{cde}$ \\
\hline $\mathrm{CV}(\%)$ & 4.30 & 4.19 & 3.61 & 4.00 & 3.31 & 3.62 \\
\hline
\end{tabular}

Means with uncommon letters in a column are significantly different at $5 \%$ level by Tukey's W test.

$\mathrm{T}_{0}=$ Control, $\mathrm{T}_{1}=\mathrm{GA}_{3}$ at $50 \mathrm{ppm}, \mathrm{T}_{2}=\mathrm{GA}_{3}$ at $75 \mathrm{ppm}, \mathrm{T}_{3}=\mathrm{GA}_{3}$ at $100 \mathrm{ppm}, \mathrm{T}_{4}=\mathrm{NAA}$ at $40 \mathrm{ppm}, \mathrm{T}_{5}=\mathrm{NAA}$ at $60 \mathrm{ppm}, \mathrm{T}_{6}=\mathrm{NAA}$ at $80 \mathrm{ppm}, \mathrm{T}_{7}=\mathrm{NAA}$ at $100 \mathrm{ppm}$

' $*$ ' indicates days after transplanting

$\mathrm{V}_{1}=$ Krishibid Hybrid $-1 ; \mathrm{V}_{2}=$ Atlas -70

The control treatment took maximum time (46.27 days) for head initiation of Krishibid Hybrid-1, which was statistically similar to all treatments except $\mathrm{GA}_{3}$ at 50 and $75 \mathrm{ppm}$. Application of $\mathrm{GA}_{3}$ at $50 \mathrm{ppm}$ initiated head formation with minimum time (38.59 days). But in Atlas-70, days to head initiation was not significantly influenced by growth regulator treatments; however, the lowest time 
was required to head initiation for the plants treated with $50 \mathrm{ppm} \mathrm{GA}_{3}(35.20$ days) followed by $75 \mathrm{ppm} \mathrm{GA} 3$ (35.42 days). The control treatment took the maximum time (76.76 days) for head maturity of Krishibid Hybrid-1; while NAA at $40 \mathrm{ppm}$ took minimum time (69.11 days) for head maturity of the same variety. In Atlas-70, the maximum time (76.76 days) was required for head maturity of the plants that were not treated with PGR and the minimum time required for head maturity of the plants that was treated with $50 \mathrm{ppm} \mathrm{GA}_{3}(70.42$ days) closely followed by 75 ppm $\mathrm{GA}_{3}$ (70.42 days) and 60 ppm NAA (70.45 days). These corroborate the results of Roy and Nasiruddin (2011), Chaurasiy et al. (2014), Afrin (2013) and Lina (2015) who recorded minimum time to head formation and head maturity from 50,60, 70 and $95 \mathrm{ppm} \mathrm{GA}_{3}$, respectively.

The maximum unfolded leaves/plant was obtained from Krishibid hybrid-1 when treated with $50 \mathrm{ppm} \mathrm{GA}$ (16.46) followed by $60 \mathrm{ppm}$ NAA (15.86) and the lowest from control (13.23). In the variety Atlas-70, $\mathrm{GA}_{3}$ at $75 \mathrm{ppm}$ produced the highest number of unfolded leaves (13.60), which was identical to $\mathrm{GA}_{3}$ at 50 ppm (13.40) and NAA at $60 \mathrm{ppm}$ (13.47).

This is in line with the results of Roy and Nasiruddin (2011), Chaurasiy et al. (2014), Mazed et al. (2015), Afrin (2013), Lina (2015) and Islam et al. (2017) who obtained maximum number of unfolded leaves/plant from 50, 60, 90, 90, 115 and $120 \mathrm{ppm} \mathrm{GA}$, respectively. Application of $\mathrm{GA}_{3}$ at $50 \mathrm{ppm}$ gave the maximum folded leaves/plant (40.89) in Krishibid Hybrid-1 which was identical with NAA at $60 \mathrm{ppm}$ (40.44). In Atlas-70, maximum number of folded leaves/plant was recorded from $\mathrm{GA}_{3}$ at $75 \mathrm{ppm}$ (48.73) which was statistically similar to NAA at 60 ppm (46.67). In both the varieties, the control treatment gave the lowest number of unfolded leaves. Similar result was also found by Roy and Nasiruddin (2011) who found that $\mathrm{GA}_{3}$ at $50 \mathrm{ppm}$ produced the highest number of folded leaves/plant. In Krishibid Hybrid-1, application of $\mathrm{GA}_{3}$ at $50 \mathrm{ppm}$ produced the highest number of total leaves/plant (57.35 and) which was identical with $\mathrm{GA}_{3}$ at $75 \mathrm{ppm},(54.39)$ and $\mathrm{NAA}$ at $60 \mathrm{ppm}$ (56.30), NAA at $40 \mathrm{ppm}$ (52.39), NAA at $80 \mathrm{ppm}$ (53.51) and NAA at $100 \mathrm{ppm}$ (50.36). But in Alas-70, the highest number of total leaves/plant (62.33) was recorded from $\mathrm{GA}_{3}$ at $75 \mathrm{ppm}$ (62.33) which was statistically similar to NAA at $60 \mathrm{ppm}$ (60.13). The superiority in growth parameters of different treatments over control might be due to foliar application of $\mathrm{GA}_{3}$ and NAA, as they have physiological effects on growth parameters of plants. The suppressive action of $\mathrm{GA}_{3}$ and NAA on apical meristem and interference with gibberellin synthesis might be resulted in cell elongation and cell division, increase in photosynthesis activity, better food accumulation and the early head formation and maturity. The fall in endogenous gibberellin levels in control might be responsible for delayed head initiation and head maturity.

\section{Effect of $\mathrm{GA}_{3}$ and NAA on chlorophyll content index (CCI) of cabbage leaf}

In both the varieties all growth regulator treatments produced higher chlorophyll content index (CCI) over control (Fig. 1). In Krishibid Hybrid-1, application of 
NAA at $60 \mathrm{ppm}$ gave the maximum CCI (64.65) which was statistically similar to $\mathrm{GA}_{3}$ at $50 \mathrm{ppm}$ (63.28); whereas, in Atlas $-70, \mathrm{GA}_{3}$ at $75 \mathrm{ppm}$ produced the maximum CCI (58.80) which was statistically similar to NAA at $60 \mathrm{ppm}$ (58.70) and $\mathrm{GA}_{3}$ at $50 \mathrm{ppm}$ (58.60). The control treatment gave the lowest CCI (45.57 in Krishibid Hybrid-1 and 51.60 in Atlas-70) in both the varieties. CCI in growth regulator treated plants might be increased due to creation of available environment for chlorophyll synthesis by application of $\mathrm{GA}_{3}$ and NAA.

Table 2. Effect of GA3 and NAA on yield components and yield of cabbage

\begin{tabular}{c|ccc|c|c|c}
\hline \multirow{2}{*}{ Treatment } & \multicolumn{2}{|c|}{ Head height $(\mathrm{cm})$} & \multicolumn{2}{c|}{ Head diameter $(\mathrm{cm})$} & \multicolumn{2}{c}{ Head compactness $(\mathrm{N})$} \\
\cline { 2 - 7 } & $\mathrm{V}_{1}$ & $\mathrm{~V}_{2}$ & $\mathrm{~V}_{1}$ & $\mathrm{~V}_{2}$ & $\mathrm{~V}_{1}$ & $\mathrm{~V}_{2}$ \\
\hline $\mathrm{T}_{0}$ & $12.37 \mathrm{~b}$ & $11.97 \mathrm{c}$ & $17.91 \mathrm{~b}$ & $17.60 \mathrm{c}$ & 9.09 & 9.00 \\
$\mathrm{~T}_{1}$ & $14.50 \mathrm{a}$ & $13.97 \mathrm{ab}$ & $23.76 \mathrm{a}$ & $21.69 \mathrm{ab}$ & 8.89 & 9.50 \\
$\mathrm{~T}_{2}$ & $13.64 \mathrm{ab}$ & $14.23 \mathrm{a}$ & $22.90 \mathrm{a}$ & $22.60 \mathrm{a}$ & 8.65 & 9.63 \\
$\mathrm{~T}_{3}$ & $13.09 \mathrm{ab}$ & $13.53 \mathrm{ab}$ & $21.53 \mathrm{ab}$ & $21.80 \mathrm{ab}$ & 8.82 & 9.60 \\
$\mathrm{~T}_{4}$ & $14.22 \mathrm{a}$ & $13.00 \mathrm{bc}$ & $21.49 \mathrm{ab}$ & $20.34 \mathrm{~b}$ & 8.92 & 9.52 \\
$\mathrm{~T}_{5}$ & $14.26 \mathrm{a}$ & $13.90 \mathrm{ab}$ & $23.64 \mathrm{a}$ & $22.42 \mathrm{ab}$ & 8.99 & 9.45 \\
$\mathrm{~T}_{6}$ & $13.96 \mathrm{a}$ & $13.47 \mathrm{ab}$ & $22.69 \mathrm{ab}$ & $21.09 \mathrm{ab}$ & 9.05 & 9.48 \\
$\mathrm{~T}_{7}$ & $13.54 \mathrm{ab}$ & $13.43 \mathrm{ab}$ & $21.02 \mathrm{ab}$ & $20.70 \mathrm{ab}$ & 8.97 & 9.52 \\
\hline $\mathrm{CV}(\%)$ & 3.76 & 4.77 & 7.72 & 3.65 & 5.90 & 4.19 \\
\hline
\end{tabular}

Table 2.cont'd.

\begin{tabular}{|c|c|c|c|c|c|c|c|c|}
\hline \multirow[t]{2}{*}{ 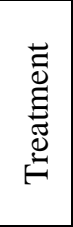 } & \multicolumn{2}{|c|}{$\begin{array}{c}\text { Single head } \\
\text { weight with } \\
\text { unfolded leaves } \\
(\mathrm{kg})\end{array}$} & \multicolumn{2}{|c|}{$\begin{array}{c}\text { Single head } \\
\text { weight without } \\
\text { unfolded leaves } \\
(\mathrm{kg})\end{array}$} & \multicolumn{2}{|c|}{ Head yield (t/ha) } & \multicolumn{2}{|c|}{$\begin{array}{c}\% \text { Head } \\
\text { yield increase } \\
\text { over } \\
\text { control }\end{array}$} \\
\hline & $\mathrm{V}_{1}$ & $\mathrm{~V}_{2}$ & $\mathrm{~V}_{1}$ & $\mathrm{~V}_{2}$ & $\mathrm{~V}_{1}$ & $\mathrm{~V}_{2}$ & $\mathrm{~V}_{1}$ & $\mathrm{~V}_{2}$ \\
\hline $\mathrm{T}_{0}$ & $2.08 \mathrm{c}$ & $2.92 \mathrm{c}$ & $1.70 \mathrm{de}$ & $2.28 \mathrm{e}$ & $67.29 \mathrm{~d}$ & $72.32 \mathrm{e}$ & - & - \\
\hline $\mathrm{T}_{1}$ & $2.74 \mathrm{a}$ & $3.79 \mathrm{ab}$ & $2.22 \mathrm{a}$ & $2.97 \mathrm{~b}$ & $81.18 \mathrm{a}$ & $94.96 \mathrm{ab}$ & 17.11 & 23.84 \\
\hline $\mathrm{T}_{2}$ & $2.33 \mathrm{~b}$ & $4.13 \mathrm{a}$ & $1.95 \mathrm{bc}$ & $3.23 \mathrm{a}$ & $75.28 \mathrm{abc}$ & $102.40 \mathrm{a}$ & 10.61 & 29.38 \\
\hline $\mathrm{T}_{3}$ & $2.10 \mathrm{c}$ & $3.41 \mathrm{bcd}$ & $1.75 \mathrm{de}$ & $2.53 \mathrm{~cd}$ & $67.57 \mathrm{~d}$ & $80.34 \mathrm{~cd}$ & 0.41 & 9.98 \\
\hline $\mathrm{T}_{4}$ & $2.64 \mathrm{a}$ & $3.18 \mathrm{de}$ & $1.60 \mathrm{e}$ & 2.39de & $75.24 \mathrm{abc}$ & $75.73 \mathrm{de}$ & 10.57 & 4.50 \\
\hline $\mathrm{T}_{5}$ & $2.70 \mathrm{a}$ & $3.58 \mathrm{bc}$ & $2.03 \mathrm{~b}$ & $2.75 b c$ & $78.57 \mathrm{ab}$ & $87.26 b c$ & 14.36 & 17.12 \\
\hline $\mathrm{T}_{6}$ & $2.43 \mathrm{~b}$ & $3.38 \mathrm{~cd}$ & $1.87 \mathrm{bcd}$ & $2.67 \mathrm{c}$ & $72.20 \mathrm{bcd}$ & $84.61 \mathrm{c}$ & 6.80 & 14.53 \\
\hline $\mathrm{T}_{7}$ & $2.38 \mathrm{~b}$ & $3.26 \mathrm{cde}$ & $1.78 \mathrm{~cd}$ & $2.57 \mathrm{~cd}$ & $68.71 \mathrm{~cd}$ & $81.54 \mathrm{~cd}$ & 2.07 & 11.31 \\
\hline $\begin{array}{l}\mathrm{CV} \\
(\%)\end{array}$ & 3.47 & 3.88 & 3.58 & 3.16 & 4.30 & 7.25 & - & - \\
\hline
\end{tabular}

Means with uncommon letters in a column are significantly different at $5 \%$ level by Tukey's W test.

$\mathrm{T}_{0}=$ Control, $\mathrm{T}_{1}=\mathrm{GA}_{3}$ at $50 \mathrm{ppm}, \mathrm{T}_{2}=\mathrm{GA}_{3}$ at $75 \mathrm{ppm}, \mathrm{T}_{3}=\mathrm{GA}_{3}$ at $100 \mathrm{ppm}, \mathrm{T}_{4}=\mathrm{NAA}$ at $40 \mathrm{ppm}, \mathrm{T}_{5}=\mathrm{NAA}$ at $60 \mathrm{ppm}, \mathrm{T}_{6}=\mathrm{NAA}$ at $80 \mathrm{ppm}, \mathrm{T}_{7}=\mathrm{NAA}$ at $100 \mathrm{ppm}$ $\mathrm{V}_{1}=$ Krishibid Hybrid $-1 ; \mathrm{V}_{2}=$ Atlas -70 
Table 3. Partial cost benefit analysis of cabbage production by the application of GA3 and NAA

\begin{tabular}{|c|c|c|c|c|c|c|c|c|c|c|}
\hline \multirow[t]{2}{*}{ Treatments } & \multicolumn{2}{|c|}{$\begin{array}{l}\text { Head yield } \\
\text { (t/ha) }\end{array}$} & \multicolumn{2}{|c|}{$\begin{array}{l}\text { Gross return } \\
\text { ('000 Tk./ha) }\end{array}$} & \multirow{2}{*}{$\begin{array}{c}\text { Cost of } \\
\text { treatment } \\
\text { ('000 } \\
\text { Tk./ha) }\end{array}$} & \multirow{2}{*}{$\begin{array}{c}\text { Total cost } \\
\text { of } \\
\text { cultivation } \\
\text { ('000 } \\
\text { Tk./ha) }\end{array}$} & \multicolumn{2}{|c|}{$\begin{array}{l}\text { Net return } \\
\text { ('000 Tk./ha) }\end{array}$} & \multicolumn{2}{|c|}{$\begin{array}{c}\text { Benefit- } \\
\text { cost ratio } \\
\text { (BCR) }\end{array}$} \\
\hline & $\mathrm{V}_{1}$ & $\mathrm{~V}_{2}$ & $\mathrm{~V}_{1}$ & $\mathrm{~V}_{2}$ & & & $\mathrm{~V}_{1}$ & $\mathrm{~V}_{2}$ & $\mathrm{~V}_{1}$ & $\mathrm{~V}_{2}$ \\
\hline $\mathrm{T}_{0}$ & 67.29 & 72.32 & 403.74 & 470.08 & 0.00 & 125.40 & 278.34 & 344.68 & 3.22 & 3.75 \\
\hline $\mathrm{T}_{1}$ & 81.18 & 94.96 & 487.08 & 617.24 & 6.25 & 135.85 & 351.23 & 481.39 & 3.59 & 4.54 \\
\hline $\mathrm{T}_{2}$ & 75.28 & 102.40 & 451.68 & 665.60 & 9.37 & 138.97 & 312.71 & 526.63 & 3.25 & 4.79 \\
\hline $\mathrm{T}_{3}$ & 67.57 & 80.34 & 405.42 & 522.21 & 12.50 & 142.10 & 263.32 & 380.11 & 2.85 & 3.67 \\
\hline $\mathrm{T}_{4}$ & 75.24 & 75.73 & 451.44 & 492.25 & 0.22 & 129.82 & 321.62 & 362.43 & 3.48 & 3.79 \\
\hline $\mathrm{T}_{5}$ & 78.57 & 87.26 & 471.42 & 567.19 & 0.33 & 129.93 & 341.49 & 437.26 & 3.63 & 4.37 \\
\hline $\mathrm{T}_{6}$ & 72.20 & 84.61 & 433.2 & 549.97 & 0.44 & 130.04 & 303.16 & 419.93 & 3.33 & 4.23 \\
\hline $\mathrm{T}_{7}$ & 68.71 & 81.54 & 412.26 & 530.01 & 0.55 & 130.15 & 282.11 & 399.86 & 3.17 & 4.07 \\
\hline
\end{tabular}

$\mathrm{T}_{0}=$ Control, $\mathrm{T}_{1}=\mathrm{GA}_{3}$ at $50 \mathrm{ppm}, \mathrm{T}_{2}=\mathrm{GA}_{3}$ at $75 \mathrm{ppm}, \mathrm{T}_{3}=\mathrm{GA}_{3}$ at $100 \mathrm{ppm}, \mathrm{T}_{4}=\mathrm{NAA}$ at $40 \mathrm{ppm}, \mathrm{T}_{5}=\mathrm{NAA}$ at $60 \mathrm{ppm}, \mathrm{T}_{6}=\mathrm{NAA}$ at $80 \mathrm{ppm}, \mathrm{T}_{7}=\mathrm{NAA}$ at $100 \mathrm{ppm} ; \mathrm{V}_{1}=$ Krishibid Hybrid-1, $\mathrm{V}_{2}=$ Atlas-70

Basic cost of cultivation: 125.40 thousand Tk./ha

Cost of PGRs::

1. Gibberellic acid $\left(\mathrm{GA}_{3}\right): \mathrm{Tk}$. 500.00/g

2. Naphthalelene Acetic Acid (NAA): Tk. 2200.00/100 g

Market selling price of head:

1. Tk. $6.00 / \mathrm{kg}$ (Tk. $6000.00 /$ ton) in 2016

2. Tk. $6.50 / \mathrm{kg}$ (Tk. $6500.00 /$ ton) in 2017

\section{Effect of $\mathrm{GA}_{3}$ and $\mathrm{NAA}$ on yield components and yield of cabbage}

Application of $\mathrm{GA}_{3}$ and NAA had significant effect on most of the yield components and yield of cabbage except head compactness (Table 2). All hormonal treatments gave higher head height and head diameter than control. The maximum head height $(14.50 \mathrm{~cm})$ and head diameter $(23.76 \mathrm{~cm})$ of Krishibid Hybrid-1 were recorded with $\mathrm{GA}_{3}$ at $50 \mathrm{ppm}$, which was statistically similar to all other treatments except control. But the maximum head height was recorded in Atlas-70 with $\mathrm{GA}_{3}$ at $75 \mathrm{ppm}(14.23 \mathrm{~cm})$ which was statistically similar to $\mathrm{GA}_{3}$ at $50 \mathrm{ppm}(13.97 \mathrm{~cm})$ and NAA at $60 \mathrm{ppm}(13.90 \mathrm{~cm})$. The highest head diameter was recorded with $\mathrm{GA}_{3}$ at $75 \mathrm{ppm}(22.60 \mathrm{~cm})$ in Atlas-70 followed by NAA at $60 \mathrm{ppm}(22.42 \mathrm{~cm})$ and $\mathrm{GA}_{3}$ at $50 \mathrm{ppm}(21.69 \mathrm{~cm})$. In Krisibid Hybrid-1, the maximum single head weight with unfolded leaves was obtained from $\mathrm{GA}_{3}$ at $50 \mathrm{ppm}(2.74 \mathrm{~kg})$ closely followed by NAA $60 \mathrm{ppm}(2.70 \mathrm{~kg})$ and NAA $40 \mathrm{ppm}$ $(2.64 \mathrm{~kg})$; whereas, the highest head weight with unfolded leaves was recorded in Atlas-70 from $75 \mathrm{ppm} \mathrm{GA}_{3}(4.13 \mathrm{~kg})$ which was statistically similar to 50 
ppm $\mathrm{GA}_{3}(3.79 \mathrm{~kg})$ and its minimum value was found in control $(2.08 \mathrm{~kg}$ in Krishibid Hybrid-1 and $2.92 \mathrm{~kg}$ in Atlas-70). Application of $50 \mathrm{ppm} \mathrm{GA}_{3}$ gave the highest single head weight without unfolded leaves $(2.22 \mathrm{~kg})$ and the control produced the lowest single head weight without unfolded leaves $(1.70 \mathrm{~kg}$ in Krishibid Hybrid-1. But in Atlas-70, the maximum head weight without unfolded leaves was obtained from the application of $\mathrm{GA}_{3}$ at $75 \mathrm{ppm}(3.23 \mathrm{~kg})$ and the control gave the lowest value $(2.28 \mathrm{~kg})$. These are in agreement with the results of Roy and Nasiruddin (2011), Chaurasiy et al. (2014), Mazed et al. (2015), Afrin (2013), Lina (2015), Paul (2011) and Islam et al. (2017) who recorded maximum head diameter, single head weight without unfolded leaves and single head weight without unfolded leaves from 50, 60, 90, 70, 95, 90 and $120 \mathrm{ppm}$ $\mathrm{GA}_{3}$, respectively.

In Krishibid hybrid-1, application of $\mathrm{GA}_{3}$ at $50 \mathrm{ppm}$ gave the maximum head yield $(81.18 \mathrm{t} / \mathrm{ha})$ being identical with NAA at $60 \mathrm{ppm}(78.57 \mathrm{t} / \mathrm{ha}), \mathrm{GA}_{3}$ at 75 ppm (75.28 t/ha) and NAA at $40 \mathrm{ppm}(75.24 \mathrm{t} / \mathrm{ha})$; whereas, the highest head yield, in Atlas-70, was recorded from $75 \mathrm{ppm} \mathrm{GA}$ (102.40 t/ha) which was statistically similar to $50 \mathrm{ppm} \mathrm{GA} 3(94.96 \mathrm{t} / \mathrm{ha})$. The minimum head yield was recorded from the control (67.29 t/ha in Krishibid Hybrid-1 and 72.32 in Atlas70). In Krishibid Hybrid-1, GA 3 at $50 \mathrm{ppm}, \mathrm{NAA}$ at $60 \mathrm{ppm}$ and $\mathrm{GA}_{3}$ at $75 \mathrm{ppm}$ increased head yield over control by $17.11,14.36$ and $10.61 \%$, respectively; whereas in ATlas-70, $\mathrm{GA}_{3}$ at 75 and $50 \mathrm{ppm}$ and NAA at $60 \mathrm{ppm}$ increased head yield over control by 29.38, 23.84 and $17.12 \%$, respectively. Islam et al. (1993), Rahman and Mondal (1995), Dhengle and Bhosale (2008) and Roy and Nasiruddin (2011) got the highest yield of cabbage at $50 \mathrm{ppm} \mathrm{GA}_{3}$. But Chaurasiy et al. (2014) obtained the maximum yield of cabbage from $\mathrm{GA}_{3}$ at 60 ppm which was statistically similar to NAA at $80 \mathrm{ppm}$. Yadav et al (2000), Mazed et al. (2015), Paul (2011), Afrin(2013), Lina (2015), and Islam et al. (2017) recorded maximum head yield from 100, 90, 90, 70, 95 and $120 \mathrm{ppm}$ $\mathrm{GA}_{3}$, respectively. The increase in weight of head and yield might be due to greater photosynthesis, higher food accumulation; better plant growth, better chlorophyll formation and higher quantum yield ( $\mathrm{Fv} / \mathrm{Fm})$ because the economic part of cabbage is head and which is formed by thick overlapping of leaves. The another probable reason for increasing yield attributes might be due to the increasing growth characters by cell division, cell elongation and cell expansion that might have ultimately increased in the head yield.

\section{Partial cost analysis}

The present study (Table 3) revealed that among the various treatments in the variety Krishibid Hybrid-1, gross return and net return were found maximum with $50 \mathrm{ppm} \mathrm{GA}$ followed by $60 \mathrm{ppm}$ NAA; whereas in the variety Atlas-70, gross return and net return were found maximum with $75 \mathrm{ppm} \mathrm{GA} 3$ followed by 50 ppm $\mathrm{GA}_{3}$ and 60 ppm NAA. In Krishibid Hybrid-1, all the treatments except $\mathrm{GA}_{3}$ and NAA both@100 ppm recorded higher benefit:cost ratio (BCR) over 
control while in Atlas-70, all the treatments except $\mathrm{GA}_{3} @ 100$ ppm recorded the maximum BCR. The highest BCR was obtained from NAA $60 \mathrm{ppm}$ (3.63) followed by 50 ppm GA 3 (3.59) in Krishibid Hybrid-1, whereas in Alas-70, the maximum BCR was obtained from 75 ppm GA 3 (4.79) followed by 50 ppm GA (4.54) and $60 \mathrm{ppm}$ NAA (4.37). The control treatment gave the lowest gross and net return in case of both varieties.

\section{Conclusion}

The results of the experiment led to the conclusion that the head yield of cabbage was greatly improved by application of $\mathrm{GA}_{3}$ and NAA. Application of $\mathrm{GA}_{3} @$ 50-75 ppm, and NAA@60 ppm increased head yield of cabbage significantly over control. In Krishibid Hybrid-1, application of GA 3 @ 50 ppm, NAA @ 60 ppm and $\mathrm{GA}_{3} @ 75$ ppm yielded 81.18,78.57 and 75.28 t/ha, respectively which was $17.11,14.36$ and $10.61 \%$, respectively over control $(67.21 \mathrm{t} / \mathrm{ha})$. On the other hand in Atlas-70, spray of $\mathrm{GA}_{3} @ 75$ and 50 ppm and, NAA @ 60 ppm produced $102.40,94.96$ and 87.26 t/ha of cabbage head, respectively which was 29.38 , 23.84 and $17.12 \%$, respectively over control. Spray of NAA @ 60 ppm to the plants of the variety Krishibid Hybrid-1 recorded the maximum benefit-cost ratio (BCR) (3.63) followed by GA 3 @ 50 ppm (3.59). But in Atlas-70, the maximum BCR was obtained from the spray of $\mathrm{GA}_{3} @ 75 \mathrm{ppm}$ (4.79) which was followed by $\mathrm{GA}_{3} @ 50$ ppm (4.54) and NAA@60 ppm (4.37). From the point of economics, it is thus inferred that the use of GA 3 @ 50-75 ppm or NAA @60 ppm could be recommended for increasing the head yield of cabbage with higher return.

\section{References}

Afrin, F. 2013. Growth and yield cabbage as influenced by gibberellic acid and phosphorous. MS Thesis. Dept. of Hort., Shere-e-Bangla Agricultural University (SAU), Dhaka-1207.

Anonymous. 2006. Effect of N P K S Zn B and Mg on yield attributes and yield of cabbage. Annual Report of 2005-2006. Soil Science Division, Bangladesh Agricultural Research Institute (BARI), Joydebpur, Gazipur-1701. pp. 15-18.

Chaurasiy, J., M. L. Meena, H. D. Singh, A. Adarsh and P. K. Mishra. 2014. Effects of $\mathrm{GA}_{3}$ and NAA on growth and yield of cabbage (Brassica oleracea var. capitata L.) cv. Pride of India. The Bioscan. 9 (3): 1139-1141.

Dhengle, R. P. and A. M. Bhosale. 2008. Effect of plant growth regulators on yield of cabbage (Brassica oleracea var. capitata). Int. J. Pl. Sci. 3 (2):376-378.

Islam, M. A., A. Siddique, M. A. Kashem. 1993. Effect of growth regulators on the growth, yield and ascorbic acid content of cabbage. Bangladesh J. Agril. Sci. 20 (1):21-27.

Islam, M. M., M. S. I. Khan, A. Parven. 2017. Growth and yield potential of late planting cabbage influenced by gibberellic acid. Int. J. Bus. Soc. Sci. Res. 6 (1):62-67. 
Kumar, D., K. D. Gujar and K. Singh. 1996. Effect of GA and NAA on growth, chlorophyll content and maturity of cabbage. Crop Res. (Hisar). 12 (1): 116-119.

Lina, J. A. 2015. Effect of planting time and gibberellic acid on the growth and yield of cabbage. MS Thesis. Dept. of Hort., Shere-e-Bangla Agricultural University (SAU), Dhaka-1207.

Mazed, H. E. M., M. H. Akand, I. J. Irin, J. F. Moonmoon and M. H. Rahman. 2015. Effect of gibberellic acid on the growth and yield of cabbage (Brassica oleracea var. capitata L.). Int. J. Appl. Res. 1 (4): 24-29.

Mello, S. C., R. T. Matsuzaki, R. Campagnol and C. F. Mattiuz. 2013. Effects of plant growth regulators in ornamental kale (Brassica oleracea var. acephala). Acta Horticulturae. 937: 245-251.

Moyazzama, K. 2018. Effect of different doses of $\mathrm{GA}_{3}$ and potassium on growth and yield of cabbage. MS Thesis. Dept. of Hort., Shere-e-Bangla Agricultural University (SAU), Dhaka-1207.

Nickell, L. G. 1982. Plant Growth regulators. Springer-Verlag Berlin Heidelberg. New York. pp.1-3.

Paul, J. 2011. Effect of $\mathrm{GA}_{3}$ and nitrogen on the growth and yield of cabbage. MS Thesis. Dept. of Hort., Shere-e-Bangla Agricultural University (SAU), Dhaka-1207.

Rahman, M. S. and M. F. Mondal. 1995. Effects of irrigation and growth regulators on the growth and yield of cabbage. Bangladesh Hort. 23 (1 \& 2): 53-57.

Roy, R. and K. M. Nasiruddin. 2011. Effect of different levels of $\mathrm{GA}_{3}$ on growth and yield of cabbage. J. Environ. Sci. Nat. Resor. 4 (2): 79-82.

Singh, N. P., A. K. Bhardway, A. Kumar and K. M. Singh. 2004. Modern Technology on Vegetable Production. Int. Book Distri. Co. Chaman Studio Building, $2^{\text {nd }}$ Floor, Charbagh Lucknow 226004, U. P., India. p. 135.

Thapa, U., R. Das, A. R. Mandal and S. Debnath. 2013. Influence of $\mathrm{GA}_{3}$ and NAA on growth, yield and quality attributing characters of sprouting broccoli [Brassica oleracea (L.) var. italica Plenk]. Crop Res. (Hisar). 46 (1/3): 192-195.

Yadav, R. L., R. S. Dhaka and M. S. Fageria. 2000. Effect of GA 3 , NAA and succinic acid on growth and yield of cabbage cv. Golden acre. J. Hort. Sci. 29 (3/4): 269-270. 